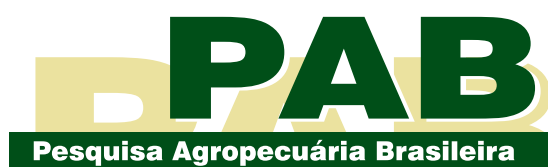

ISSN 1678-3921

Journal homepage: www.embrapa.br/pab

For manuscript submission and journal contents, access: www.scielo.br/pab

Edson Eyi Sano(1凶) ${ }^{(1)}$, Roberto Rosa(2) Carlos Alberto de Mattos Scaramuzza( ${ }^{(3)}$, Marcos Adami(4) Edson Luis Bolfe ${ }^{(5)}$, Alexandre Camargo Coutinho(6) ${ }^{(3)}$, Júlio César Dalla Mora Esquerdo(6) (-), Luís Eduardo Pinheiro Maurano (7) , Igor da Silva Narvaes ${ }^{(4)}$, Francisco José Barbosa de Oliveira Filho ${ }^{(8)}$, Elaine Barbosa da Silva(9) ${ }^{(9)}$, Daniel de Castro Victoria ${ }^{(6)}$, Laerte Guimarães Ferreira(9) , Jorge Luís Silva Brito(2) , Adriana Panhol Bayma ${ }^{(3)}$

(3), Gustavo Henrique de Oliveira ${ }^{(3)}$ and Gustavo Bayma-Silva ${ }^{(10)}$

(1) Instituto Brasileiro do Meio Ambiente e dos Recursos Naturais Renováveis, SCEN Trecho 2, Edifício Sede, Bloco C, L4 Norte, CEP 70818-900 Brasília, DF, Brazil. E-mail: edson.sano@ibama.gov.br

(2) Universidade Federal de Uberlândia, Instituto de Geografia, Campus Santa Mônica, Avenida João Naves de Ávila, no 2.121, Santa Mônica, CEP 38400-902 Uberlândia, MG, Brazil. E-mail: rrosa@ufu.br, jbrito@ufu.br

${ }^{(3)}$ Ministério do Meio Ambiente, Secretaria de Biodiversidade, SEPN 505 Norte, Bloco B, Edifício Marie Prendi Cruz, CEP 70730-542 Brasília, DF, Brazil. E-mail: carlos.scaramuzza@mma.gov.br, adriana.bayma@mma.gov.br, floresteiro77@gmail.com

(4) Instituto Nacional de Pesquisas Espaciais, Centro Regional da Amazônia, Parque de Ciência e Tecnologia do Guamá, Avenida Perimetral, oo 2.651, CEP 66077-830 Belém, PA, Brazil. E-mail: marcos.adami@inpe.br, igor.narvaes@inpe.br

${ }^{(5)}$ Embrapa Sede, Secretaria de Inteligência e Relações Estratégicas, Parque Estação Biológica, s/non, CEP 70770-901 Brasília, DF, Brazil. E-mail: edson.bolfe@embrapa.br

(6) Embrapa Informática Agropecuária, Avenida André Tosello, № 209, Campus da Unicamp, Barão Geraldo, Caixa Postal 6041 , CEP 13083-886 Campinas, SP, Brazil. E-mail: alex.coutinho@embrapa.br, julio.esquerdo@embrapa.br daniel.victoria@embrapa.br

(7) Instituto Nacional de Pesquisas Espaciais, Avenida dos Astronautas, ํo 1.758, Jardim da Granja, CEP 12227-010 São José dos Campos, SP, Brazil.

E-mail: maurano@dpi.inpe.br

\section{Land use dynamics in the Brazilian Cerrado in the period from 2002 to 2013}

\begin{abstract}
The objective of this work was to analyze land use dynamics in the Brazilian Cerrado region from 2002 to 2013. This analysis was based on the interpretation of Landsat satellite images carried out by the projects Projeto de Conservação e Utilização Sustentável da Diversidade Biológica Brasileira (Probio) and TerraClass Cerrado 2013, both coordinated by Ministério do Meio Ambiente. In 2002, 38.9\% of the Cerrado was covered by some type of anthropic activity. In 2013, this percentage increased to $43.4 \%$. One of the main highlights is the emergence of a new agricultural frontier in the northern region of the study area, known as Matopiba.
\end{abstract}

Index terms: Landsat, Probio, remote sensing, TerraClass Cerrado.

\section{Dinâmica do uso das terras no Cerrado no período de 2002 a 2013}

Resumo - O objetivo deste trabalho foi analisar a dinâmica de uso das terras na região do Cerrado de 2002 a 2013. Essa análise foi baseada nas interpretações de imagens do satélite Landsat realizadas pelo Projeto de Conservação e Utilização Sustentável da Diversidade Biológica Brasileira (Probio) e pelo projeto TerraClass Cerrado 2013, coordenados pelo Ministério do Meio Ambiente. Em 2002, 38,9\% do Cerrado eram cobertos por algum tipo de atividade antrópica. Em 2013, essa percentagem passou para 43,4\%. Um dos grandes destaques é o surgimento de uma nova fronteira agrícola na região norte da área de estudo, conhecida como Matopiba.

Termos para indexação: Landsat, Probio, sensoriamento remoto, TerraClass Cerrado.

The Brazilian Cerrado (tropical savanna) is the second largest biome in the country, covering approximately 204 million hectares in the central uplands (IBGE, 2004), where it faces the most intensive land use pressure. Mean annual rainfall ranges from 800 to $1,800 \mathrm{~mm}$, with marked climatic seasonality, i.e., six-month dry season, from April to September, and six-month wet season, from October to March. Soils are deep, well drained, with low levels of fertility and high Al and Si toxicity. Natural vegetation corresponds to varying proportions of grasses, shrubs, and trees. The two most important land use types are: cultivated pasturelands, primarily with African Urochloa grass species, for cattle ranching; and rainfed croplands, mostly soybean, corn, cotton, and coffee.

In the Cerrado, land use mapping based on satellite images is difficult because of extensive and persistent cloud cover conditions in 


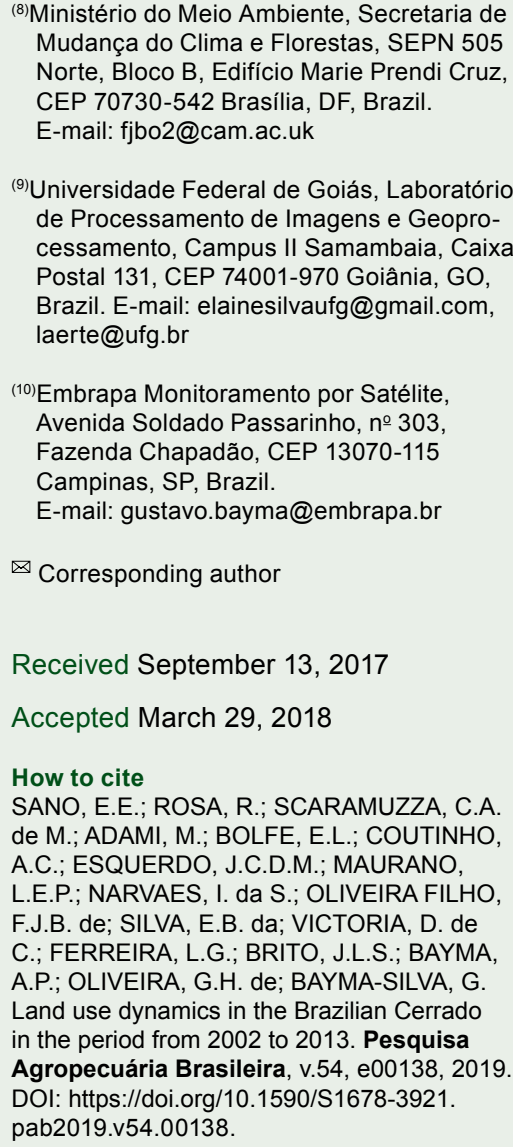

some areas, highly sensitive climatic seasonality, and high dynamics within land use classes (Silva \& Sano, 2016). However, producing accurate land use maps of the biome is important, for example, to monitor biomass changes and related $\mathrm{CO}_{2}$ emissions due to habitat conversion and degradation, as well as to define public policies either to prevent deforestation and degradation or to define the best strategies and priorities for biodiversity conservation.

Up to now, land use mapping in the Cerrado biome has focused on the use of medium spatial resolution $(30 \mathrm{~m})$ and optical satellite images. The first "wall-to-wall" land use map, encompassing the entire Cerrado, was prepared in 2002 based on the interpretation of more than 120 Landsat images by Projeto de Conservação e Utilização Sustentável da Diversidade Biológica Brasileira (Probio) (Sano et al., 2008, 2010) under the coordination of Ministério do Meio Ambiente (MMA). More recently, Beuchle et al. (2015) analyzed land cover changes in the Brazilian Cerrado and Caatinga biomes from 1990 to 2010, based on a systematic remote sensing sampling approach; according to the authors, in 2010, the estimated percentage of land use in the Cerrado was $53 \%$. Another initiative named Projeto de Monitoramento do Desmatamento nos Biomas Brasileiros por Satélite (PMDBBS), conducted by Instituto Brasileiro do Meio Ambiente e dos Recursos Naturais Renováveis (Ibama), reported a 49\% land use in the Cerrado in 2010 (PMDBBS, 2017).

Hansen et al. (2013) used the Google Cloud Platform and the Global Land Analysis \& Discovery (GLAD) platform to map global and annual tree cover extent for 2000-2012. In 2015, MMA coordinated another land use mapping project of the Cerrado, known as TerraClass Cerrado 2013 (hereafter, TerraClass Cerrado), using Landsat-8 images (Mapeamento..., 2015). According to the project Projeto de Mapeamento Anual da Cobertura e Uso do Solo do Brasil (MapBiomas), based on the analysis of time series of Landsat data and on the Google Engine platform, the percentage of land use was $49 \%$ in 2016 (MapBiomas, 2017).

It should be noted that the studies carried out by PMDBBS and Beuchle et al. (2015) do not allow the long term ( $>10$ years) analysis of land use dynamics. In addition, the usability and consistency of the results obtained by GLAD have been questioned by some authors, such as Tropek et al. (2014), especially in the seasonal tropical domains. Because they are quite recent, the annual land use maps from MapBiomas have not yet been evaluated by the scientific community. In this context, Probio and the TerraClass are currently the best options for the long-term analysis of land use dynamics in the Cerrado. Such analysis is important to estimate the rate of loss of natural vegetation in the biome, as well as to estimate the ongoing conversion between different land use types, particularly the level of conversion of pasturelands into croplands.

The objective of this work was to analyze land use dynamics in the Brazilian Cerrado region from 2002 to 2013 .

Although the mapping projects Probio and TerraClass Cerrado both used images obtained by the Landsat satellite series, i.e., Landsat-7 Enhanced Thematic Mapper Plus (ETM+) and Landsat-8 Operational Land Imager (OLI), respectively, it is important to point out the main differences and similarities between them when comparing results. In Probio, the minimum mapping area was defined as 40 ha and, in TerraClass Cerrado, as 6.25 ha, which resulted in a finer detail map for 2013. Moreover, non-identified areas (burned 
and cloud covered), bare soil, and mosaic of occupation (areas composed of a mixture of varying land use classes, such as houses, orchards, native vegetation, and relatively small pastures that cannot be defined as specific polygons) were only included in the TerraClass Cerrado legend. The final product of TerraClass Cerrado also received an independent validation, which showed a high overall accuracy of $80.2 \%$ (Mapeamento..., 2015). However, in the two developed products, the areas mapped as pasture refer only to the cultivated pastures, whereas natural vegetation represents the areas covered with native vegetation species, regardless of the presence of some type of land use, as cattle on natural grasslands (native pastures).
In the present study, the vector-based maps of Probio and TerraClass Cerrado, in shapefile format, were used to calculate the areas, in hectares, occupied by the major land use classes in the Cerrado biome; for this, the Calculate Geometry tool available in the ArcGIS software, version 10.2 (Environmental Systems Research Institute, Redlands, CA, USA), was adopted. A transition matrix was also used to determine the magnitude of changes in the major land cover types. In the experimental period, land use in the Cerrado increased from $38.9 \%$ (about 80 million hectares), in 2002, to $43.4 \%$ (about 88.5 million hectares) in 2013 (Figure 1). This corresponds to an average increase of $0.41 \%$ per year, i.e., to 772 thousand hectares per

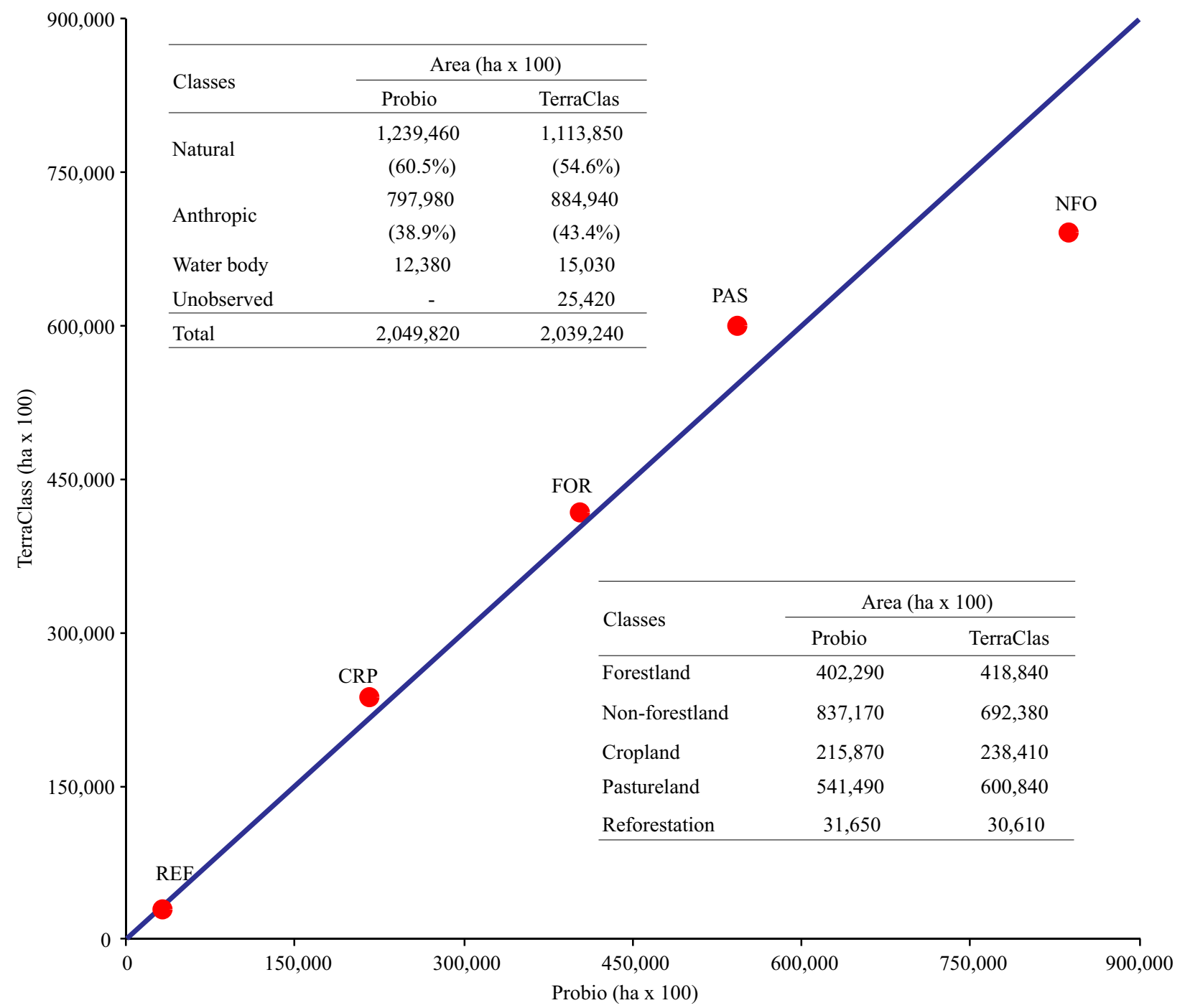

Figure 1. Scatterplot between land use cover data from 2002 and 2013 obtained by Projeto de Conservação e Utilização Sustentável da Diversidade Biológica Brasileira (Probio) and by TerraClass Cerrado 2013, respectively, for the five major land use classes in the Brazilian Cerrado biome. REF, reforestation; CRP, croplands; FOR, forestlands; PAS, cultivated pasturelands; and NFO, non-forestlands. 
year of new clear cuttings. This result is in alignment with that from PMDBBS (2017), which estimated an average annual deforestation of $0.34 \%$, representing 712 thousand hectares per year, between 2008 and 2011. Pasturelands increased from 54 to 60 million hectares, while croplands went from 22 to 24 million hectares. Reforestation presented similar results.

The confusion matrix between Probio and Terra Class Cerrado data indicated that 5.3 million hectares of cultivated pasture in 2002 were converted into croplands in 2013 and that another 1.1 million hectares were converted into reforestation, especially with Eucalyptus. Approximately 19.1 and 3.7 million hectares of natural vegetation in 2002 were converted into cultivated pastures and into croplands, respectively, in 2013.

Table 1 shows the areas occupied by pasturelands and croplands in 2002 and 2013 at the state level. The increase in areas occupied by croplands and cultivated pasturelands was $11 \%$ for both types of land use. However, the most noticeable feature is the significant increase in croplands of 128,328 , 286 , and $41 \%$ in the states of Maranhão, Tocantins, Piauí, and Bahia, respectively. Estimates from the survey on agricultural production, Produção Agrícola Municipal (IBGE, 2017), showed similar increases for soybean [Glycine $\max (\mathrm{L}$.) Merr.] planted area in the region: $136 \%$ for Maranhão, $400 \%$ for Tocantins, $533 \%$ for Piauí, and $51 \%$ for Bahia. Despite the different methodologies and uncertainties related to each project, the high magnitude of crop expansion in these states was captured by both datasets. This highlights the importance of the region encompassing these states, known as Matopiba (Miranda et al., 2014), the new agricultural frontier of the Cerrado. Matopiba covers approximately 45 million hectares and 151 municipalities and is already responsible for 10 and $15 \%$ of the national production of soybean and corn (Zea mays L.), respectively (Esquerdo et al., 2015).

The analysis of the maps produced by the Probio and TerraClass Cerrado projects showed that, from 20022013, the Cerrado biome lost its natural vegetation at a rate of $0.41 \%$ per year. This is much higher than the deforestation rate of $0.29 \%$ per year reported for Amazônia Legal during the same time period (INPE, 2018). The major changes in land use and cover were related to the conversion of natural vegetation into cultivated pastures and croplands, as well as of cultivated pastures into croplands.

Table 1. Area and percentage occupied by cultivated pasturelands and croplands, the two largest types of land use in the Brazilian Cerrado, per year and per state.

\begin{tabular}{|c|c|c|c|c|c|c|c|}
\hline \multirow[t]{2}{*}{ State } & \multirow{2}{*}{$\begin{array}{c}\text { State }^{(1)} \\
(\%)\end{array}$} & \multicolumn{2}{|c|}{ Cropland area $\left(\mathrm{km}^{2} \times 100\right)$} & \multirow{2}{*}{$\begin{array}{c}\text { Increase } \\
(\%)\end{array}$} & \multicolumn{2}{|c|}{ Pastureland area $\left(\mathrm{km}^{2} \times 100\right)$} & \multirow{2}{*}{$\begin{array}{c}\text { Increase } \\
(\%)\end{array}$} \\
\hline & & 2002 & 2013 & & 2002 & 2013 & \\
\hline Piauí & 37 & 21.5 & 83.0 & 286 & 52.1 & 60.3 & 16 \\
\hline Maranhão & 65 & 35.6 & 81.0 & 128 & 190.1 & 337.4 & 77 \\
\hline Tocantins & 91 & 17.6 & 75.4 & 328 & 425.3 & 547.7 & 29 \\
\hline Bahia & 27 & 157.3 & 222.2 & 41 & 225.7 & 245.0 & 9 \\
\hline Mato Grosso & 40 & 556.1 & 583.9 & 5 & 650.9 & 791.1 & 22 \\
\hline Minas Gerais & 57 & 212.2 & 312.0 & 47 & $1,183.8$ & $1,187.6$ & 0 \\
\hline Goiás & 97 & 503.8 & 443.2 & -12 & $1,293.2$ & $1,397.7$ & 8 \\
\hline Distrito Federal & 100 & 13.7 & 9.6 & -30 & 12.0 & 14.2 & 18 \\
\hline Mato Grosso do Sul & 61 & 271.2 & 181.2 & -33 & $1,094.8$ & $1,218.1$ & 11 \\
\hline Paraná & 2 & 8.3 & 8.9 & 7 & 10.4 & 7.2 & -31 \\
\hline São Paulo & 33 & 358.6 & 383.7 & 7 & 262.2 & 202.2 & -23 \\
\hline Rondônia & 0.2 & 0.0 & 0.0 & 0 & 0.0 & 0.1 & 0 \\
\hline Total & & $2,155.9^{(2)}$ & $2,384.1$ & 11 & $5,400.5$ & $6,008.6$ & 11 \\
\hline
\end{tabular}




\section{Acknowledgments}

To Global Environment Facility (GEF) of World Bank, for funding the projects Projeto de Conservação e Utilização Sustentável da Diversidade Biológica Brasileira (Probio) and TerraClass Cerrado; to Instituto Brasileiro de Geografia e Estatística (IBGE), for technical advising; to Conselho Nacional de Desenvolvimento Científico e Tecnológico (CNPq), to Fagro Soluções Agrícolas, and to Fundação PróNatureza (Funatura), for administrative support; and to two anonymous reviewers, for highly relevant contributions.

\section{References}

BEUCHLE, R.; GRECCHI, R.C.; SHIMABUKURO, Y.E.; SELIGER, R.; EVA, H.D.; SANO, E.; ACHARD, F. Land cover changes in the Brazilian Cerrado and Caatinga biomes from 1990 to 2010 based on a systematic remote sensing sampling approach. Applied Geography, v.58, p.116-127, 2015. DOI: https://doi.org/10.1016/j.apgeog.2015.01.017.

ESQUERDO, J.C.D.M.; COUTINHO, A.C.; SANCHES, L.B.; RIBEIRO, B.M. de O.; ZAKHAROV, N.Z.; TERRA, T.N.; MANABE, V.D. Dinâmica da agricultura anual na região do Matopiba. In: SIMPÓSIO BRASILEIRO DE SENSORIAMENTO REMOTO, 17., 2015, João Pessoa. Anais... São José dos Campos: INPE, 2015. p.4583-4588.

HANSEN, M.C.; POTAPOV, P.V.; MOORE, R.; HANCHER, M.; TURUBANOVA, S.A.; TYUKAVINA, A.; THAU, D.; STEHMAN, S.V.; GOETZ, S.J.; LOVELAND, T.R.; KOMMAREDDY, A.; EGOROV, A.; CHINI, L.; JUSTICE, C.O.; TOWNSHEND, J.R.G. High-resolution global maps of 21stcentury forest cover change. Science, v.342, p.850-853, 2013. DOI: https://doi.org/10.1126/science.1244693.

IBGE. Mapa de Biomas e de Vegetação. 2004. Available at: <http://www.ibge.gov.br/home/presidencia/ noticias/21052004biomashtml.shtm>. Accessed on: Aug. 132017.
IBGE. Sistema IBGE de Recuperação Automática - SIDRA. Available at: <https://sidra.ibge.gov.br/>. Accessed on: Aug. 20, 2017.

INPE. Instituto Nacional de Pesquisas Espaciais. Monitoramento da floresta amazônica brasileira por satélite: projeto de estimativa de desflorestamento da Amazônia: Prodes digital. Available at: <http:/www.obt.inpe.br/OBT/assuntos/ programas/ amazonia/prodes $>$. Accessed on: Mar. 20, 2018.

MAPBIOMAS: Dados atualizados, versão 2.3, dez. 2017. Available at: <http://mapbiomas.org/>. Accessed on: Mar. 27, 2018.

MAPEAMENTO do uso e cobertura do Cerrado: Projeto TerraClass Cerrado 2013. Brasília: Ministério do Meio Ambiente, 2015. 67p.

MIRANDA, E.E.; MAGALHÃES, L.A.; CARVALHO, C.A. Proposta de delimitação territorial do MATOPIBA. Campinas: Embrapa, 2014. 18p. (Embrapa. Nota técnica, 1).

PMDBBS. Projeto de Monitoramento do Desmatamento dos Biomas Brasileiros por Satélite. Monitoramento do Cerrado. Available at: <http://siscom.ibama.gov.br/monitora_biomas/ PMDBBS\%20-\%20CERRADO.html>. Accessed on: June 25, 2017.

SANO, E.E.; ROSA, R.; BRITO, J.L.S.; FERREIRA, L.G. Land cover mapping of the tropical savanna region in Brazil. Environmental Monitoring and Assessment, v.166, p.113-124, 2010. DOI: https://doi.org/10.1007/s10661-009-0988-4

SANO, E.E.; ROSA, R.; BRITO, J.L.S.; FERREIRA, L.G. Mapeamento semidetalhado do uso da terra do Bioma Cerrado. Pesquisa Agropecuária Brasileira, v.43, p.153-156, 2008. DOI: https://doi.org/10.1590/S0100-204X2008000100020.

SILVA, L. da R. da; SANO, E.E. Análise das imagens do satélite RapidEye para discriminação da cobertura vegetal do bioma Cerrado. Revista Brasileira de Cartografia, v.68, p.1269-1283, 2016.

TROPEK, R.; SEDLÁCEK, O.; BECK, J.; KEIL, P.; MUSILOVÁ, Z.; SIMOVÁ, I.; STORCH, D. Comment on "high-resolution global maps of 21st-century forest cover change". Science, v.344, p.981, 2014. DOI: https://doi.org/10.1126/science.1248753. 